Reprod. Nutr. Dévelop., 1981, 21 (6B), 1105-1112.

\title{
Testis development and daily sperm output in guinea-fowl raised under constant daily photoperiods
}

by J. P. BRILLARD, M. de REVIERS

Station de Recherches avicoles, I.N.R.A. Nouzilly, 37380 Monnaie, France.

Summary. The testicular growth of guinea-fowis in relation to age was compared under 3 constant photoperiods (7L : 17D; 14L : 10D ; 20L : 4D) from 3 weeks of age. Although long daylength (14L or $20 \mathrm{~L}$ ) caused precocious development of the gonads, it also limited total adult gonadal weight to around $1800 \pm 200 \mathrm{mg}$. Short daylengths (7L) delayed the development of the gonads but their adult weight was enhanced to $2800 \pm 200 \mathrm{mg}$.

A comparison of the changes in daily sperm output (DSO) under $7 \mathrm{~L}: 17 \mathrm{D}$ and $14 \mathrm{~L}: 10 \mathrm{D}$ was consistent with the observations on testis weights. Under neither photoschedule was a correlation found between individual age at first ejaculate and the individual DSO observed at sexual maturity. However, the mean individual DSO's estimated from the first 10 ejaculates were correlated to those observed at sexual maturity, and the latter were also correlated to the DSO's observed at 53-55 or 59-61 weeks of age.

\section{Introduction.}

Reports on reproduction in the guinea-fowl are not numerous although it has been domesticated for a long time and is an important agricultural product. Barbier ef Leroy (1970) described seasonal variations in the testicular development of guineafowls fed ad libitum but submitted to natural climatic conditions (geographical location of the experiment : latitude $490 \mathrm{~N}$ ). Maximal gonadal development was observed during the summer (May to September : $2.5 \pm 1.0 \mathrm{~g}$ ) and the minimum appeared between October and January $(0.5 \pm 0.5 \mathrm{~g})$.

In equatorial regions of Africa, reproduction in wild species of guinea-fowls occurs at any time during the year, but the appearance of a breeding season is more marked as the latitude increases (for example, it only occurs between March and May in Morocco: Barbier and Leroy, 1970).

These observations support the idea that photoperiodism may be an important factor regulating reproduction in the guinea-fowl. The present paper describes for the first time changes in testis weight and sperm output under short and long constant photoperiods in controlled environmental conditions.

\section{Materials and methods.}

Experiment 1. - 360 one-day-old male guinea-fowls were divided into 3 batches (120 chicks in each). All the animals were fed and allowed water ad libitum (table 1) 
TABLE 1

Composition of the diets distributed « ad libitum » in the 3 trials

\begin{tabular}{lccc}
\hline & $\begin{array}{c}0-6 \text { weeks } \\
\text { (starting period) }\end{array}$ & $\begin{array}{c}7-16 \text { weeks } \\
\text { (growing period) }\end{array}$ & $\begin{array}{c}17-61 \text { weeks } \\
\text { (adult period) }\end{array}$ \\
\hline $\begin{array}{l}\text { Metabolizable }(\mathrm{kcal} / \mathrm{kg}) \ldots \ldots \\
\text { Energy } \quad(\mathrm{MJ} / \mathrm{kg}) \ldots \ldots\end{array}$ & 3150 & 3000 & 2600 \\
\hline $\begin{array}{c}\text { Crude protein Level } \\
(\mathrm{N} \times 6.25) \ldots \ldots \ldots \ldots\end{array}$ & 13.2 & 12.5 & 10.9 \\
\hline
\end{tabular}

throughout the experiment which lasted 70 weeks. They were reared on the ground till the age of 16 weeks, then individually caged. The ambient temperature was maintained at $35^{\circ} \mathrm{C}$ until 3 weeks of age, at $32^{\circ} \mathrm{C}$ up to 6 weeks and at $20^{\circ} \mathrm{C}$ thereafter. The photoperiod was gradually reduced to either 20L : 4D (at 1 week of age, group 1), 14L :10D (at 2 weeks of age, group 2) or 7L : 17D (at 3 weeks of age, group 3 ). These daily photoperiods were then respectively maintained until the end of the experiment (throughout the text, $L$ refers to the hours of illumination and $D$ to the hours of darkness).

The animals were individually weighed at various ages, from the 8 th to the 51 st week after hatching. At 8, 12,16,20,24, 28, 34, 39, 51 and 70 weeks of age, 10 animals in each group were killed and autopsied. The testes were immediately weighed to the nearest $\mathrm{mg}$.

Experiment 2. - Using similar conditions of temperature, feeding and housing, 2 of the above photoschedules (14L:10D and 7L:17D) were replicated and 72 males were submitted to each. In these animals, semen collections were performed twice a week at various periods between 22 and 61 weeks of age by a massage technique derived from Burrows and Quinn (1935).

This frequency of semen collection allows the maximum number of ejaculated spermatozoa per male to be obtained (table 2).

TABLE 2

Variations in the sperm output as a function of the semen collection frequency

\begin{tabular}{|c|c|c|c|}
\hline $\begin{array}{l}\text { Frequency of collection (times a } \\
\text { week) } \ldots \ldots \ldots \ldots \ldots \ldots \ldots \ldots \ldots \ldots\end{array}$ & 1 & 2 & 3 \\
\hline Number of males ${ }^{*}$ collected..... & 54 & 54 & 54 \\
\hline $\begin{array}{l}\text { Number of spermatozod ejaculated } \\
\text { each week (in millions) }{ }^{* *} \ldots \ldots \ldots\end{array}$ & 174 & 371 & 361 \\
\hline
\end{tabular}

* All males, raised under the same environmental conditions were collected over four consecutive weeks. The number of sperm is expressed as the mean of the 3 last weeks.

${ }_{* *} F=20$ for 2 , and $160 \mathrm{DF}$, highly significant differences appear between 1 vs 2 and 3 semen collections per week. No significant differences were observed between 2 and 3 semen collections/week.

Each ejaculate was individually weighed to the nearest $\mathrm{mg}$ and the results converted into volume (specific gravity of semen $\simeq 1 \mathrm{mg} / \mu \mathrm{l}$ ). This method was found to be 
more precise and quicker than pipetting because of the small volume of the ejaculates produced by guinea-fowl (range : 0-200 $\mu l$ ).

The sperm concentration of semen was evaluated by optical density at $600 \mathrm{~nm}$ (fig. 1). This allowed the total number of spermatozoa per ejaculate to be calculated, from which the daily sperm output (DSO) (Amann, 1970) was obtained. A highly significant correlation was observed between DSO and testicular weight (fig. 2).

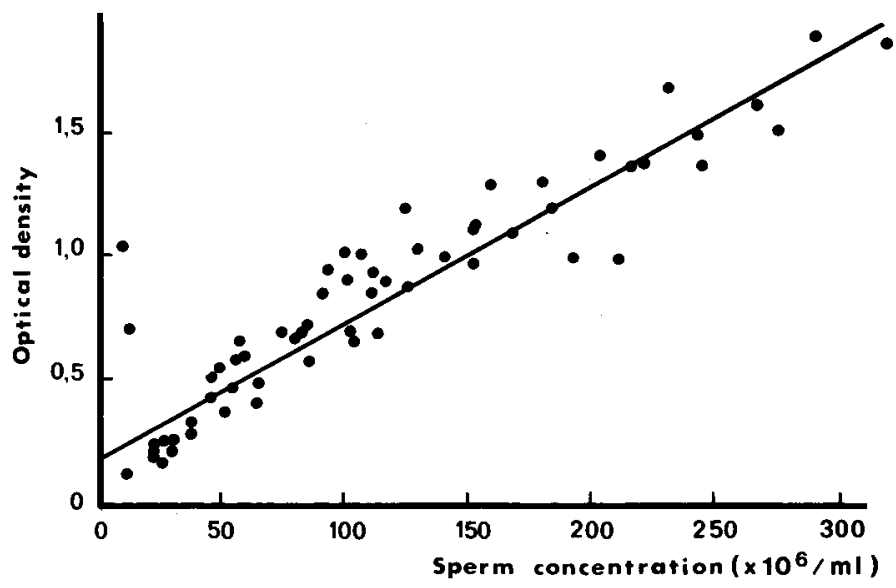

FIG. 1. - Relationship between the fofal number of spermatozoa (counted with hemocytometers *) and oplical density measured in the same ejaculates. $* 10$ replications per ejaculate. Total number of ejaculates 0 t 60. Wavelength : $600 \mathrm{~nm}$. Equation of regression : $y=0.170+0.0056 \times(r=0.96)$.

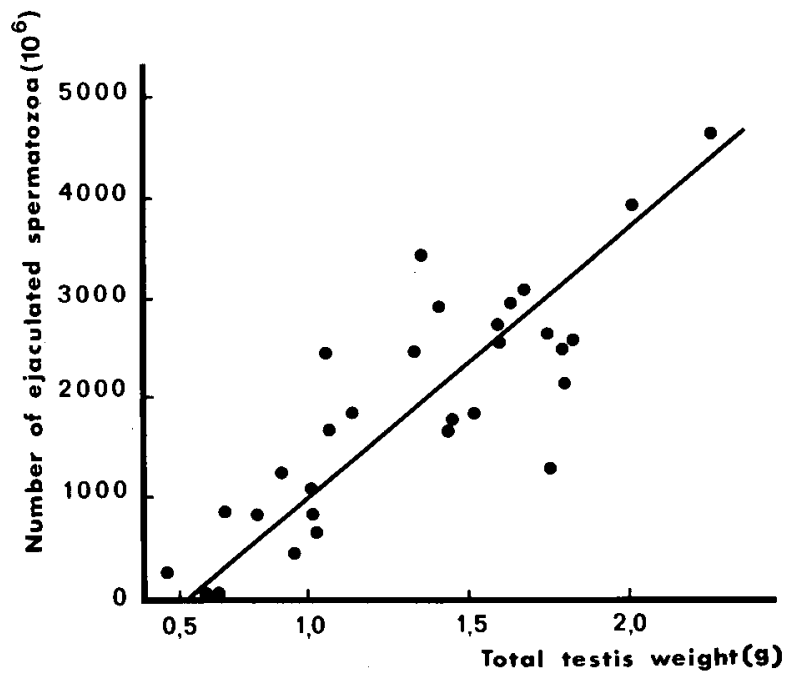

FIG. 2. - Relationship observed between the fotal testis weight and the number of ejaculated spermatozoa in guinea-fowl. All the males, placed under a 14L/10D light regime, were collected twice a week between 66 and 68 weeks of age. - Linear regression : $Y=1753.5+2748.5 \times(r=0.84)$. 
As the sperm reserves contained in the deferent ducts may introduce bias when estimating sperm production by sperm output (Ortavant, 1958 ; de Reviers, 1972), the males were ejaculated twice during the week preceding each period of ejaculate measurement.

Experiment 3. - The mean individual DSO was estimated for 3 different periods in 15 and 45 males raised under $7 \mathrm{~L}: 17 \mathrm{D}$ and $14 \mathrm{~L}: 10 \mathrm{D}$, respectively. Period I involved the first 10 ejaculates from individuals (mean respective ages at start : 27-28 and 2122 weeks). Period II involved consecutive ejaculates from individuals at the end of the testicular growth phase (corresponding ages at start : 46-47 and 24-26 weeks). Period III involved 6 similar ejaculates between 53 and 61 weeks of age.

\section{Results.}

\section{Experiment 1.}

1. Body weight was quite similar under each photoschedule until 28 weeks of age ; it decreased unexpectedly between $20(1600 \pm 50 \mathrm{~g})$ and 24 weeks $(1480 \pm 50 \mathrm{~g})$ of age under each photoschedule, and then increased again, the highest levels occurring

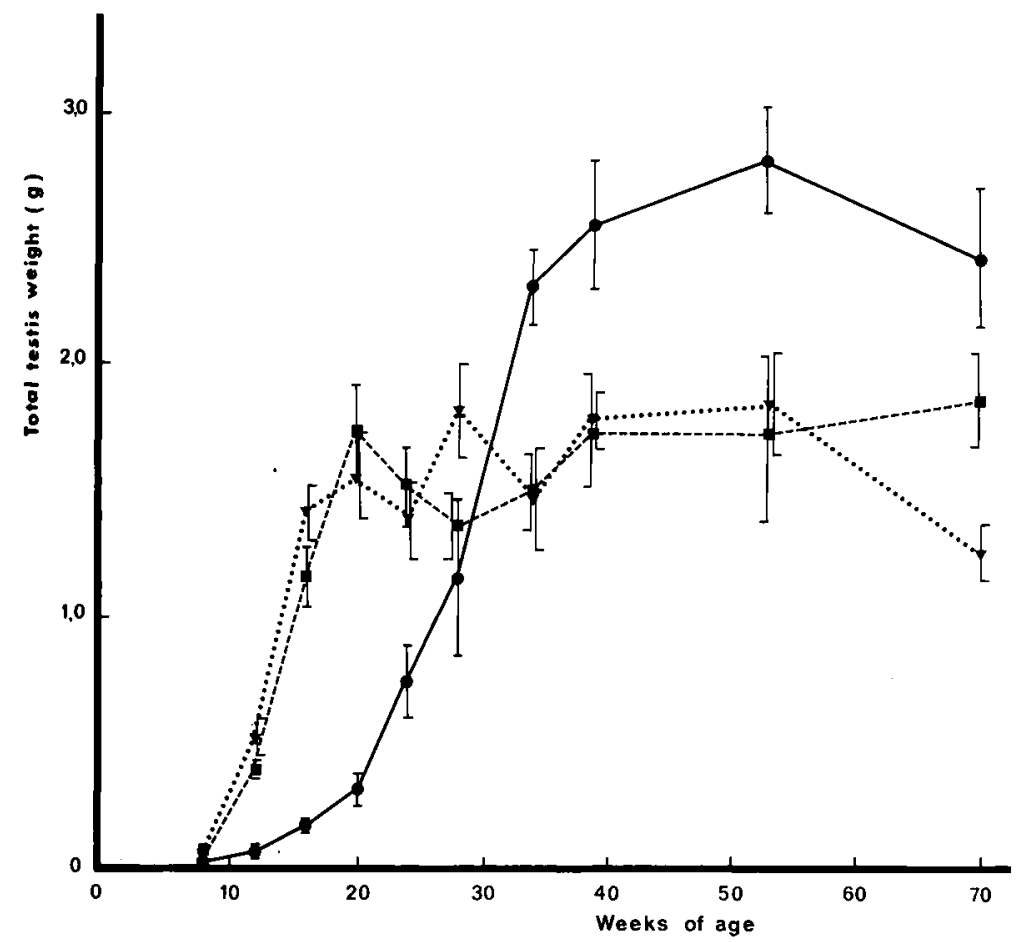

FIG. 3. - A comparison of the changes in total testis weight with age in guinea fowls raised and mainfained under three constant light regimes. Each point represents the mean testis weight $\bar{x} \pm S E M$ of 5 birds. Photoschedules : $\longrightarrow 7 \mathrm{~L}: 17 \mathrm{D} ; \mathrm{a}-\cdots 14 \mathrm{~L}: 10 \mathrm{D} ; \nabla \ldots \nabla 2 \mathrm{~L}: 4 \mathrm{D}$. 
under $7 \mathrm{~L}: 17 \mathrm{D}$ and the lowest under $20 \mathrm{~L}: 4 \mathrm{D}(1900 \pm 50 \mathrm{~g}$ vs $1600 \pm 30 \mathrm{~g}$ at 51 weeks of age). Under $14 \mathrm{~L}: 10 \mathrm{D}$ and $20 \mathrm{~L}: 4 \mathrm{D}$, body weight appeared to be stabilized at 39 weeks of age.

2. Testicular development (fig. 3) was very similar under 20L : 4D and 14L:10D. After a rapid increase from 8 to 20 weeks of age $(60-80 \mathrm{mg}$ up to $1400-1600 \mathrm{mg})$, the mean testicular weight was stable up to 51 weeks of age. It decreased thereafter only under the 20L : 4D photoschedule (1 $240 \pm 100 \mathrm{mg}$ at 70 weeks of age).

In contrast, the testes developed much later under $7 \mathrm{~L}: 17 \mathrm{D}$, reaching their maximum weight at 51 weeks of age. This weight was higher than the maximum observed under long photoperiods (2800 mg vs $1800 \mathrm{mg}$ ), but it was not statistically different from that observed at 34,39 and 70 weeks under the same treatment $(F=0.99)$.

Experiment 2. - The number of spermatozoa collected, expressed on a per day basis (daily sperm output), is shown in figure 4 (for 14L : 10D and 7L : 17D photoschedules). The DSO reached $30 \times 10^{6}$ spermatozoa at 23 weeks of age in males maintained under $14 \mathrm{~L}: 10 \mathrm{D}$ compared to 28 weeks of age in males maintained

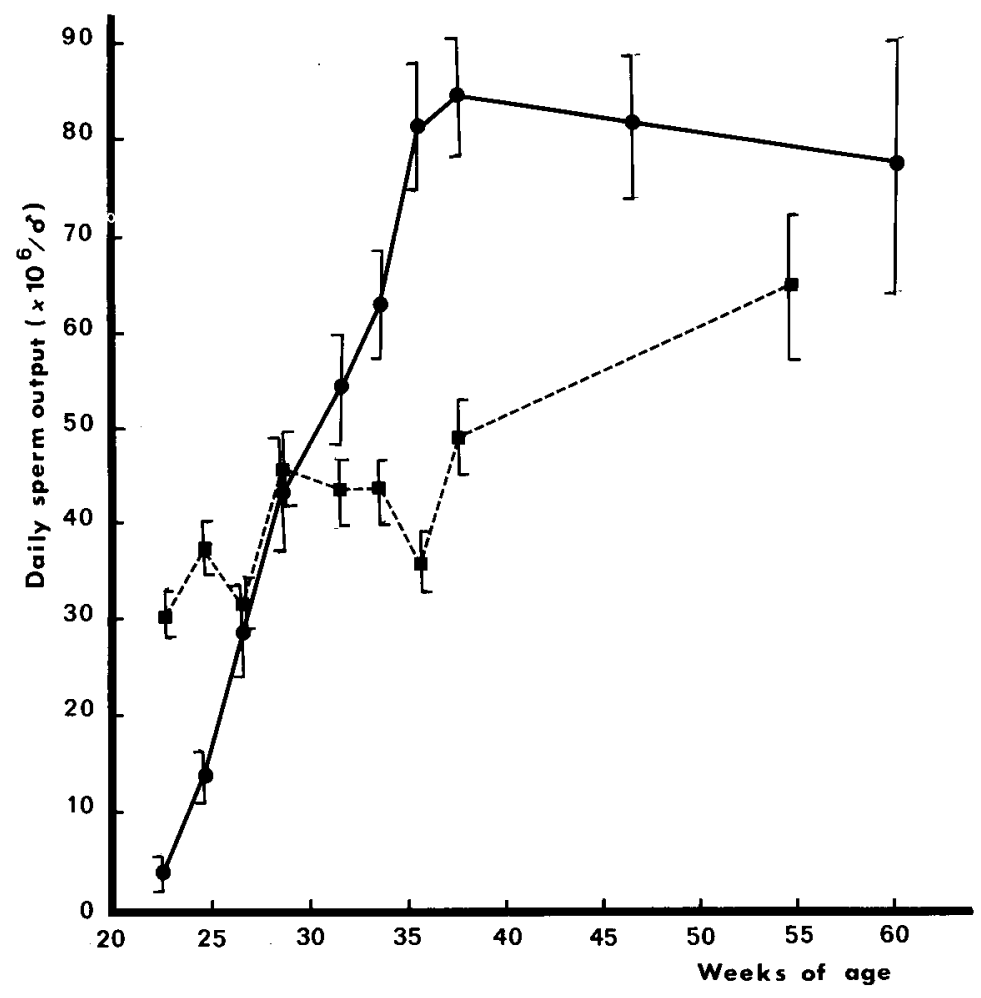

FIG. 4. - A comparison of the changes in daily sperm output (DSO) of guinea fowls placed under $7 L / 17 D$ or $14 L / 10 D$ photoperiods. Each point represents the mean of two consecutive weeks $\pm S E M$. Photo-

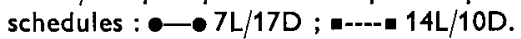


under 7L : 17D. Afterwards, under 14L : 10D, there was a slow, linear increase in the DSO from 23 to 55 weeks of age (30 to $64 \times 10^{6}$ sperm). In animals exposed to $7 \mathrm{~L}: 17 \mathrm{D}$, the DSO reached a maximum of $84 \times 10^{6} \mathrm{sperm} /$ day at 38 weeks of age, and then slowly decreased until the end of the experiment.

Experiment 3. - Table 3 shows the results of the DSO observed in the same animals during 3 different age periods. A significant correlation $(P<0.05)$ was obtained between periods I and II and III in both groups and between periods I and III in the 14L : 10D group. On the other hand, the ages at which the first ejaculate for each male were obtained were not found to be either positively or negatively correlated with adult or late individual sperm production in either group $(r<0.25)$.

TABLE 3

DSO levels and correlations befween inifial, early and late adult sperm output obtained in guinea-fowls raised under 7L-17D or 14L/10D light regimes

\begin{tabular}{|c|c|c|c|c|c|c|}
\hline & \multicolumn{3}{|c|}{ Stage of development } & \multicolumn{3}{|c|}{$\begin{array}{c}\text { Correlation between stages } \\
\quad \text { (individual DSO) }\end{array}$} \\
\hline & $\begin{array}{c}\text { I } \\
\text { Early sperm } \\
\text { production }\end{array}$ & $\begin{array}{c}\text { II } \\
\text { Sexual } \\
\text { maturity }\end{array}$ & $\begin{array}{l}\text { III } \\
\text { Later } \\
\text { adult }\end{array}$ & RI-II & R II-III & RI-III \\
\hline $\begin{array}{l}7 \mathrm{~L}: 17 \mathrm{D}(15 \text { males }) \\
\text { No. of ejaculates } / \text { male ..... } \\
\text { Mean age (weeks) at start.. } \\
\text { Mean DSO }\left(\times 10^{6} / \text { day }\right) \ldots\end{array}$ & $\begin{array}{c}10 \\
27-28 \\
23 \pm 4\end{array}$ & $\begin{array}{c}6 \\
46-47 \\
75 \pm 12\end{array}$ & $\begin{array}{c}6 \\
59-61 \\
75 \pm 12\end{array}$ & $\overline{\overline{-}}$ & $\overline{\overline{-}} \overline{80}$ & $\frac{\overline{-}}{0.23 \mathrm{~N} . \mathrm{S}}$ \\
\hline $\begin{array}{l}\text { 14L : } 10 \mathrm{D} \text { ( } 45 \text { males) } \\
\text { No. of ejaculates } / \text { male .... } \\
\text { Mean age (weeks) at start.. } \\
\text { Mean DSO }\left(\times 10^{6} / \text { day }\right) . . .\end{array}$ & $\begin{array}{c}10 \\
21-22 \\
37 \pm 3\end{array}$ & $\begin{array}{c}6 \\
24-26 \\
37 \pm 3\end{array}$ & $\begin{array}{c}6 \\
53-55 \\
66 \pm 6\end{array}$ & $\frac{\bar{Z}}{0.73^{* *}}$ & $\frac{\bar{Z}}{0.40^{* *}}$ & $\overline{\bar{F}}$ \\
\hline
\end{tabular}

$\left.\begin{array}{l}\text { * Significant at } 5 \text { p. } 100 \text { level } \\ \text { * Significant at } 1 \text { p. } 100 \text { level }\end{array}\right\} 3$ way Anvar.

\section{Discussion.}

It may be concluded from the above results that testicular development and sperm output in the guinea-fowl are strongly influenced by daylength when constant daily photoperiods are used. These photoperiods, however, do not induce considerable modifications in body growth, as in the cockerel (Parker and Mc Cluskey, 1964 ; de Reviers, 1974) and the turkey (Krueger et al., 1977).

The variations in the testicular development observed under either short or long constant daylengths in the guinea-fowl are more similar to those reported in the furkey (Krueger et al., 1977) than in the cockerel. In the latter species, using Rhode $\times$ Wyandotte M519 cockerels, the rapid phase of testicular growth started at the same age (16 weeks) under 16L : 8D or $8 \mathrm{~L}: 16 \mathrm{D}$. Furthermore, the difference in the ages at which testicular growth terminated under these photoperiods was only 2-4 weeks (de 
Reviers, 1974). In turkeys raised under $8 \mathrm{~L}: 16 \mathrm{D}$, the mean testicular weight observed at 30 weeks of age was only half of that observed at the same age under 15L :9D $(14.2 \pm 7.9 \mathrm{~g}$ vs $33.5 \pm 13.4$, Krueger ef al., 1977). This implies a difference between species either in the age at which the rapid phase of testicular growth starts, or in the growth rate of the testes, or both. At the end of testicular growth, the difference in the mean testicular weights observed in cockerels raised under 8L : 16D or 16L : 8D was clearly noticeable $(16.8 \pm 1.4$ vs $19.5 \pm 0.8 \mathrm{~g}$ at 24 weeks of age, de Reviers et al., 1974). A positive effect of long constant photoperiods on the level of testicular development in the adult cockerel was observed. In contrast, the adult testis weight of turkeys raised under long days (15L : 9D) was much lower than under short days (8L : 16D) ( $36.5 \pm 6.4$ vs $66.2 \pm 20.2 \mathrm{~g}$; Krueger ef al., 1977).

There appears to be, therefore, a strong species $x$ daylength interaction with respect to testicular development under constant daily photoperiods. This might result from divergencies in photosensitive thresholds, which are known to be very different between wild and domestic species. The white-crowned sparrow, for instance, does not show testicular growth when submitted to a daily photoperiod of less than $9 \mathrm{hrs}$ of light per day (Farner, 1957), while in the cockerel, development to the adult condition can occur, though slowly, even when the daily photoperiod is restricted to half an hour (Nalbandov, 1970). However, it is also known that testicular growth results from a coincidence between the light and a photosensitive phase occurring during the $24 \mathrm{hr}$. cycle (Bünning, 1936 ; Follett and Sharp, 1969) and subjected to circadian periodicity. The time at which this phase occurs and its duration, might vary between different species of birds as it does in mammals (Ortavant, 1977).

Another problem is the apparent antagonism between the precocious development of the testis and its adult weight found here in the guinea-fowl and, elsewhere, in the cockerel (de Reviers, 1975) and the turkey (Krueger ef al., 1977). This antagonism, occurring under various photoschedules (constant daylengths in the guinea-fowl and turkey, but increasing daylengths in the cockerel) is in fact observed between photoschedules. Within a given photoschedule, the results of this study of DSO in the guineafowl do not show any correlation between age at first ejaculate and the DSO level observed when testicular development is terminated. The situation is probably the same for testicular development as for DSO.

Furthermore, wide individual variations in testicular weight and DSO were observed in the guinea-fowl irrespective of age and photoperiod, a situation similar to that in the cockerel (de Reviers and Williams, 1981). In both species, the individual DSO results obtained during the growth of the testes were well correlated with those observed at sexual maturity; this presents an interesting possibility for selecting males before they are used for breeding purposes. The ranking of the males might result, at least partly, from the sizes of Sertoli and stem spermatogonia populations which are determined during the prepuberal period.

Workshop on "Avion male reproduction 》 Nouzilly, France, June 1980.

Résumé. Le développement testiculaire de pintades a été comparé sous 3 photopériodes quotidiennes constantes ( $7 \mathrm{~L}: 17 \mathrm{~N} ; 14 \mathrm{~L}: 10 \mathrm{~N} ; 20 \mathrm{~L}: 4 \mathrm{~N})$ appliquées à partir de 3 semaines d'âge. Alors que les jours longs ( $14 \mathrm{~L}: 20 \mathrm{~N}$ ) provoquent un développement précoce des testi- 
cules, ils ont aussi pour conséquence de diminuer leur poids total à l'âge adulte aux environs de $1800 \pm 200 \mathrm{mg}$. Les jours courts ( $7 \mathrm{~L})$ retardent le développement des testicules mais leur poids total à l'âge adulte atteint $2800 \pm 200 \mathrm{mg}$.

Les variations du nombre de spermatozoïdes récoltés sous $7 \mathrm{~L}$ ou $14 \mathrm{~L}$ sont en bon accord avec celles observées pour le poids des testicules. Sous ces deux photopériodes, l'âge au premier éjaculat et les nombres moyens de spermatozoïdes récoltés à l'âge adulte ne sont pas corrélés. Par contre, les nombres de spermatozoïdes contenus dans les 10 premiers éjaculats sont corrélés avec les nombres de spermatozoïdes récoltés vers la fin du développement des testicules et ces derniers sont eux-mêmes corrélés avec ceux observés à 53-55 (14L) ou 59-61 (7L) semaines d'âge.

\section{References}

AMANN R. P., 1970. Sperm production rates. In The testis, A. D. JOHNSON, W. R. GOMES, N. L. VANDEMARK, vol. 1, 433-482. Acad Press.

BARBIER Y., LEROY P., 1970. Cycle annuel du testicule de la pintade. Bull. Biol., 104, 119-147.

BUNNING E., 1936. Die endogene Tagesrhyłmik als Grundlage der Photoperiodischen Reaktion. Ber. Dent. Bot., 54, 590-607.

BURROWS W. H., QUINN J. P., 1935. A method of obtaining spermatozoa from the domestic fowl. Poult. Sci., 14, 251-253-254.

FARNER D. S., 1957. Avian photoperiodic testicular response and function of the hypothalamohypophysial axis. The Physiologist, 1, 26 (abstr.).

FOLLETT B. K., SHARP P. J., 1969. Circadian rhythmicity in photoperiodically induced gonatrophin release and gonadal growth in the quail. Nature, 223, 968-971.

KRUEGER K. K., OWEN J. A., KRUEGER C. E., FERGUSON T. M., 1977. Effect of feed or light restriction during the growing and breeding cycles in the reproductive performances of broadbreasted white turkey males. Poult. Sci., 56, 1566-1574.

NALBANDOV A. V., 1970. Endocrine background of light action. In La photorégulation de la reproduction chez les oiseaux ef les mammifères, C.N.R.S. éd., Montpellier, 17-22 juillet 1967, 29-52.

ORTAVANT R., 1958. Le cycle spermatogénétique chez le bélier. Th. Doct. Etat, Univ. Paris.

ORTAVANT R., 1977. Photoperiodic regulation of reproduction in the sheep, 58-71. In Management reproduction in sheep and goats Symposium, Madison (Wisconsin).

PARKER J. E., Mac CLUSKEY W. H., 1964. The effect of the length of daily light periods on the volume and fertilizing capacity of semen from male chickens. Poult. Sci., 43, 1401-1405.

REVIERS M. de, 1972. Evaluation de la production des spermatozoïdes chez le coq. Ann. Biol. anim. Bioch. Biophys., 12, 1-18.

REVIERS M. de, 1974. Le développement festiculaire chez le coq. III. Influence de la durée quotidienne d'éclairement sous photopériodes constantes. Ann. Biol. anim. Bioch. Biophys., 14, 591-600.

REVIERS M. de, 1975. Le développement testiculaire du coq. IV. Etude quantitative des cellues germinales du coq placés sous des photopériodes croissantes appliquées à des âges différents. Ann. Biol. anim. Bioch. Biophys., 15, 633-641.

REVIERS M. de, WILLIAMS J., 1981. Predicting the adult daily sperm output after the first ejaculates in cockerels raised under different pholoschedules. Reprod. Nutr. Dévelop., 21, 1113-1124. 